instrument is that of Mr. Peelor, of Johnstown, Pennsylvania, used with great success and satisfaction by the Signal Service. This needs no battery, no electricity, to work it. A simple clock-work is all that is required, and its operations are as exquisitely accurate and trustworthy as the best navy chronometer.

A barograph and thermograph made by Mr. Beck, of London, similar to those used in the Kew Observatory, are on trial in the Signal Office, and good results are hoped from them. Their beautiful machinery might also be mentioned and described, but our space fails. Indeed, our limits have allowed mention to be made only of the most noyel instruments employed by the signal offices. A specimen record of one of these is presented in Fig. IO, showing the synchronous readings, on a given day and at a given place, of the thermometers (wet and dry bulb), the hygrometer, and the barometer, all upon one sheet of paper.

We have already spoken of the beautiful adaptation of Prof. Hough's Meteorograph to the work of printing its own registrations. The mechanics of meteorology have been advanced one step higher than this, and the registrations of the automaton are instantly and perfectly photographed. The sheet of paper, suitably prepared for photographic impressions, is made to slide, by means of clock-work, before a gas flame. The mercury in the tubes protects a portion of the paper from the action of the light of the lamp, while above the mercury the rays of the lamp fall unobstructed upon the paper, and, making their impression, reveal the exact height of the mercury in the tubes.

The "photograph of a storm," Fig. II, shows the movements of the mercury in the two thermometers and barometer for twelve hours.

This process, by which the weather is photographed, is employed by General Myer, and these necessarily exact records will prove most attractive pictorial representations of the great storms in the atmospheric ocean for the study of meteorologists all over the world.

\section{THE INTERNATIONAL EXHIBITION AT VIENNA FOR 1873}

$7 \mathrm{HE}$ Emperor of Austria has appointed an Imperial Commission to carry out the project of an International Exhibition to be held at Vienna in 1873 . The members of the Commission held their inaugural meeting in the hall of the Imperial Academy of Sciences at Vienna on Sunday, the 17 th of September, under the presidency of the Archduke Rainer.

The Exhibition is intended to be opened on the Ist of May, I873, under the especial patronage of the Emperor and his brother, the Archduke Charles Louis. The Commission, which is composed after the models of the English and French Commissions, consists of the Archduke Rainer, president ; the Lord Steward of the Imperial Household, Prince zu Hohenlohe-Schillingsfürst ; the Imperial Chancellor, Minister of the Imperial House and for Foreign Affairs, Count von Beust ; Prince zu Liechtenstein. Prince Schwarzenberg, Count Festetitz, and Count Potocki, vicepresidents; and the Lord High Chamberlain, Count Folliot de Crenneville, and other high courtiers, the Ministers and heads of departments, the Presidents of both Houses of the Reichsrath, the presidents of the chief artistic, commercial, and scientific societies, and a number of gentlemen who have distinguished themselves in the various branches of science, art, and industry.

The entire arrangements have been entrusted to the Austrian Consul-General at Paris, Privy Councillor Baron de Schwarz-Senborn, who has been nominated DirectorGeneral of the Exhibition. Local committees are about to be formed in the various provinces of Austria and Hungary, and a special Royal Commission is to be appointed at Pesth. The objects to be exhibited will be classified into 26 different groups, as detailed in the suboined programme.

One great feature of the Exhibition will be an arrangement for the classification of the productions of all countries in groups corresponding with their geographical position, and great pains will be taken to render the Oriental department in every way worthy of the almost inexhaustible resources of the Indian Empire. The position of Vienna is admirably adapted for this, having, besides the waters of the Danube, a direct communication with all the important harbours of the Levant vid Trieste. The arrangement of the Eastern department will be confided to the Austrian Consul at Constantinople, Dr. de Schwegel, who has already acquired a great reputation for his knowledge of Oriental habits and productions.

A new feature of the Exhibition will be an arrangement by which the treasured collections of the various museums of London, Paris, Berlin, Moscow, Lyons, Munich, Stuttgard, \&c., will appear in simultaneous position, and it is further intended to represent a history of inventions, a history of prices, a history of industry, and a history of natural productions, so that the world's progress in arts, science, industry, and natural products, will thus be brought into contrast. The Emperor of Austria has granted the use of the "Prater" for the site of the exhibition, and Mr. Scott Russell is at present in Vienna consulting with Baron von Schwarz as to the design for the building. Chevalier de Schaeffer, Director of the Austrian Consulate General in London, who gained great experience at the London and Paris Exhibitions, has been entrusted with the preliminary arrangements respecting the contributions to be sent to the Exhibition from Great Britain.

The objects to be exhibited will be classified in the following twenty-six groups :-I, Mining and Metallurgy; 2, Agriculture and Forestry ; 3, Chemical industry ; 4, Articles of food as industrial products ; 5 , Textile industry and clothing ; 6, Leather and india-rubber industry ; 7, Metal industry ; 8, Wood industry; 9, Stone, Earthenware, and Glass industry; IO, Hardware industry ; iI, Paper industry; 12, Graphical Arts and Industrial Drawing; 13 , Machinery and means of transport; 14 , Scientific instruments; I5, Nautical instruments; 16, Military accoutrements ; I7, Maritime objects ; I8, Architectural and Engineering objects; 19, Cottage houses, their interior arrangements and decorations; 20, Peasant houses, with their implements and arrangements; $2 \mathrm{I}$, National domestic industry; 22, Representation of the operation of Museums of Art and Industry; 23, Eccle. siastical Art ; 24, Objects of Art and Industry of former times, exhibited by amateurs and collectors ; 25, Plastic Art of the present time; 26, Objects of Education, Training, and Mental Cultivation.

Arrangements will be made for temporary exhibitions of such articles which by their nature do not admit of an exposition of long duration.

During the time the Exhibition is held, International Congresses are contemplated for the discussion of important questions to which either the Exhibition itself may give rise, or which may be specially suggested as themes suitable for international consideration.

The arrangement of the Exhibition will be geographical, that is to say, according to countries, but in such a manner that the different territories of production shall appear as nearly as possible in the same order as they are situated naturally in the direction from the west to the east.

\section{SCIENTIFIC USE OF THE MONT CENIS TUNNEL}

$A^{T}$ the sitting of the French Academy of Sciences on the 18 th inst., $M$. Elie de Beaumont read an elaborate paper on the scientific instruction which may be derived from a close examination of the collection which is to 